\title{
Tradução
}

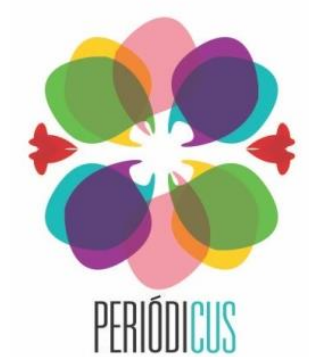

\section{O Tempo da Escravidão ${ }^{1}$}

ISSN: 2350-7844

п. 14, v. 1 nav.2020-abr.2021

(The Time of Slavery)

(El Tiempo de la Esclavitud)

Saidiya Hartman ${ }^{2}$

$\|$

Tradução:

Kênia Freitas ${ }^{3}$

Cíntia Guedes ${ }^{4}$

Matheus Araujo dos Santos ${ }^{5}$

RESUMO: Neste texto Saidiya Hartman elabora questões sobre diáspora e luto a partir de sua visita ao Castelo da Costa do Cabo e ao Castelo de Elmina, em Gana, e à Casa dos Escravos, na Ilha de Gorée, no Senegal. Percebendo as articulações entre memória e turismo, a autora tensiona narrativas oficiais e encenações do luto, considerando o tempo da escravidão como um evento contínuo que nos faz "contemporâneas das mortas".

PALAVRAS-CHAVE: escravidão; memória; luto; diáspora. Abstract: In this text Saidiya Hartman elaborates questions about diaspora and mourning from her visit to Cape Coast
Castle and Elmina Castle, in Ghana, and to the House of Slaves, in Goré Island, Senegal. Perceiving the articulations
between memory and tourism, the author tensions official narratives and mourning performances, considering the time of
slavery as a continuous event that makes us "contemporaries of the dead".

Keywords: slavery; memory; mourning; diaspora.

Resumen: En este texto, Saidiya Hartman elabora preguntas acerca de la diáspora y el duelo a partir de su visita a los castillos de Cape Coast y Elmina, en Ghana, ya la Casa de los Esclavos, en la isla de Gorée, Senegal. Percibiendo las articulaciones entre memoria y turismo, la autora cuestiona narrativas oficiales y performances de duelo, considerando el tiempo de la esclavitud como un hecho continuo que nos convierte en "contemporáneos de las muertas".

Palabras clave: esclavitud; memoria; luto; diáspora.

${ }^{1}$ The Time of Slavery - Publicado originalmente em South Atlantic Quarterly, Volume 101, no. 4, 2002, pp. 757777. Copyright 2002 by Duke University Press.

${ }^{2}$ Professora da Columbia University.

${ }^{3}$ Pesquisadora Independente.

${ }^{4}$ Professora da Universidade Federal da Bahia.

${ }^{5}$ Professor da Universidade do Estado da Bahia. 
Para mim, a história não foi um grande palco repleto de comemorações, bandas, aplausos, fitas, medalhas, o som de um copo fino tilintando e erguido no ar; em outras palavras, os sons da vitória. Para mim, a história não era apenas o passado: era o passado e também era o presente. Não me importava com minha derrota, apenas com o fato de que tivesse que durar tanto tempo; Não vi o futuro, e talvez é assim que devesse ser.

—Jamaica Kincaid, The Autobiography of My Mother

A escravidão aqui é um fantasma, tanto o passado quanto a presença viva; e o problema da representação histórica é como representar o fantasma.

-Michel-Rolph Trouillot, Silencing the Past

Uma placa memorial colocada perto da entrada do pátio do Castelo de Elmina diz: “"Em memória eterna da angústia de nossas ancestrais ${ }^{6}$. Que aquelas que morreram descansem em paz. Que aquelas que retornam encontrem suas raízes. Que a humanidade nunca mais cometa tal injustiça contra a humanidade. Nós, que estamos vivas, juramos defender isso”. Como a placa sugere, acertar as contas com a nossa responsabilidade com as mortas exige não apenas a nossa lembrança, mas também uma promessa de repúdio à injustiça que permitiu que esse crime contra a humanidade ocorresse. Parece que as nossas vidas e até as das mortas dependem de tais atos de recordação. No entanto, a melhor forma de lembrar das mortas e representar o passado é uma questão repleta de dificuldades, se não uma questão em absoluta disputa.

A dificuldade imposta pela injunção da placa para lembrar é tanto a fé que ela evidencia nas capacidades reparadoras da memória, como a confiança que ela trai na distinção fundamental ou quebra entre o então e o agora. Pois a distinção entre o passado e presente naufraga no sofrimento interminável gerado pela escravidão e suas consequências. Como podemos entender o luto, quando o evento ainda não terminou? Quando as lesões não apenas perduram, mas são infligidas de uma nova maneira? Pode-se lamentar o que ainda não deixou de acontecer? O ponto aqui não é negar a abolição da escravidão ou afirmar a identidade ou continuidade do racismo ao longo dos séculos, mas considerar a natureza constitutiva da perda na produção da diáspora

6 Privilegiamos a tradução com concordância no feminino por entender os limites da intervenção no texto original e, ao mesmo tempo, propor uma consonância com o lugar de enunciação da autora. Uma proposta limite de tradução, que não resolve as problemáticas do binarismo de gênero na língua portuguesa, mas se esforça por redirecionar as violências que desde aí se desdobram, e esbarra nos seus próprios limites e constituição de novas violências. [N.T] 
africana e o papel do luto na identificação transatlântica, especialmente à luz da ordem da placa, de que as que retornam encontrem suas raízes, o que vem após apenas do desejo de que as mortas descansem em paz.

Tento abordar essas questões examinando o papel do turismo como veículo da memória, especificamente as performances turísticas no Castelo da Costa do Cabo e no Castelo de Elmina, em Gana, e na Casa dos Escravos, na Ilha de Gorée, Senegal, e as maneiras pelas quais as identificações e os anseios da turista, as fórmulas do turismo de raízes [roots tourism] e as necessidades econômicas dos estados Africanos moldam, afetam e influenciam nossa compreensão da escravidão e, em conjunto, produzem uma memória coletiva do passado. ${ }^{7}$

Como a placa sugere, lembrar das mortas é reparar as linhas rompidas de descendência e filiação. Nesse sentido, a lembrança está envolvida em reivindicar o passado, apaziguar ancestrais e recuperar as origens das descendentes dessa dispersão. Lembrar-se da escravidão é imaginar o passado como o "tecido de nossa própria experiência" e aproveitá-lo como "a chave da nossa identidade". ${ }^{8}$ E o retorno tardio da turista afro-americana está cheio dessas questões. A fixação nas raízes revela a centralidade da identidade não apenas nas transações do turismo, mas na encenação do encontro com o passado. A identificação e o enlutamento estão inextricavelmente vinculados neste caso; já que as raízes que somos encorajadas a recuperar pressupõem a ruptura do comércio transatlântico de escravas e da alienação natal e sem parentesco da escravidão. Em outras palavras, as questões de enlutamento e a nossa identificação com as mortas são centrais tanto para o trabalho de luto, quanto para a imaginação política da diáspora africana. ${ }^{9}$ E, por esse motivo, o luto é um termo central no vocabulário político da diáspora.

Observando uma série de práticas - a troca de cartas de boas-vindas e bom retorno, o papel do Estado na fabricação de uma memória comum da escravidão, performances turísticas e peregrinações de turistas afro-americanas de classe média -, decidi explorar o tempo da

7 Em uma reunião realizada em Accra, Gana, em abril de 1995, a Organização Mundial do Turismo e a UNESCO redigiram uma declaração para "promover o desenvolvimento econômico e humano e reabilitar, restaurar e promover a herança tangível e intangível transmitida pelo comércio de escravos para fins do turismo cultural, lançando em relevo a natureza comum do tráfico de escravos em termos de África, Europa, Américas e Caribe”. UNESCO, The WTO-UNESCO Cultural Tourism Programme, The Accra Declaration (Paris: UNESCO, 1995).

8 Walter Benn Michaels, "Slavery and the New Historicism," em The Americanization of the Holocaust, ed. Hilene Flanzbaum (Baltimore: The Johns Hopkins University Press, 1999), 188.

9 Sigmund Freud, "Mourning and Melancholia,"' em The Standard Edition of the Complete Psychological Work of Sigmund Freud, vol. 14 (London: Hogarth Press, 1995); Nicholas Abraham and Maria Torok, "Mourning or Melancholia: Introjection versus Incorporation," em The Shell and the Kernel, ed. and trans. Nicholas Rand (Chicago: University of Chicago Press, 1994). 
escravidão, isto é, a relação entre o passado e o presente, o horizonte da perda, o legado existente da escravidão, as antinomias da redenção (um princípio salvador que nos ajudará a superar o dano da escravidão e a longa história de derrota) e da irreparabilidade. Ao considerar o tempo da escravidão, pretendo perturbar as narrativas redentoras elaboradas pelo Estado em sua orquestração do luto, as promessas de filiação oferecidas por comerciantes mesquinhos e as fantasias de origem encenadas nesses locais da escravidão. Da mesma forma, o "tempo da escravidão" nega a intuição do senso comum do tempo como continuidade ou progressão, o então e o agora coexistem; somos contemporâneas das mortas.

Um componente central do Programa de Turismo Cultural da UNESCO e da Organização Mundial do Turismo nas Rotas dos Escravos é o desenvolvimento do "turismo de raízes", ou seja, produtos turísticos e excursões voltados para norte-americanas em busca de suas raízes. Aqui, interessa-nos os tipos de identificação facilitados e o grau em que são determinados pela localização nacional e pelo imaginário político das turistas afro-americanas, pela estratégia de desenvolvimento dos Estados africanos e pela realização dessas excursões turísticas como o retorno das exiladas e deslocadas. Embora não seja implausível nem exagerado descrever as pessoas da diáspora como crianças exiladas ou afastadas, questiono a suficiência ou adequação do "retorno" como uma maneira de descrever essa jornada transatlântica, em que algumas foram tão longe ao ponto de recriar uma "Travessia reversa" ["reverse Middle Passage"] ${ }^{10}$ e a natureza desse encontro com o passado. Até que ponto a jornada da "estrangeira nativa" pode ser chamada de retorno ${ }^{11}$ Como alguém pode voltar para um lugar que nunca foi ou nunca viu? $\mathrm{O}$ retorno, então, é uma figura que substitui uma linguagem mais adequada de anseio e distanciamento e que contradiz a inegável e definitiva diferença ao tentar consertar o irreparável?

Se o Pan-africanismo foi animado pelo desejo de uma "unidade de sentimento e ação" entre África e a diáspora, um retorno à terra ancestral, uma nostalgia permanente e anseios não satisfeitos e talvez irrealizáveis de solidariedade em todo o mundo preto, então esse desejo foi engendrado pelo cativeiro, pela deportação e pela morte. ${ }^{12}$ A perda fixa o nosso olhar no passado, determina o presente e talvez até eclipse uma visão do futuro. W. E. B. Du Bois descreveu esse horizonte bloqueado de possibilidade e momento duradouro de lesão como

10 Nesse texto, optamos por traduzir "Middle Passage" por "Travessia" entendendo a possibilidade de aproximação entre os conceitos e a maior familiaridade do segunda pelas perspectivas negras brasileiras [N.T.].

11 Tomo este termo emprestado de Eddy L. Harris, Native Stranger: A Black American's Journey into the Heart of Africa (New York: Simon and Schuster, 1992).

12 St.Clair Drake, "Diaspora Studies and Pan-Africanism," em Global Dimensions of the African Diaspora, ed. Joseph E. Harris (Washington, DC: Howard University Press, 1982). 
crepúsculo. É, como Jamaica Kincaid escreve, “a hora [...] na qual tudo o que você perdeu está mais pesado em sua mente; sua mãe, se você a perdeu; sua casa, se você a perdeu, as vozes de pessoas que podem ter te amado ou que você apenas desejou que possam ter te amado [...] Tais sentimentos de anseios e perda são mais fortes nessa luz”. Está anoitecendo há quatrocentos anos. Se esse passado não passa, é porque o futuro, o desejado, ainda não é atingível. Essa situação e esse anseio têm séculos de idade.

Anseio e perda figuram centralmente nas estratégias do turismo de raízes - a perda das origens, nomes africanos autênticos, progenitores e terras ancestrais agem como um ímpeto para visitar, adquirir e comprar. O turismo atenua o anseio, explora a perda e oferece uma cura, permitindo engajamentos catárticos e lacrimosos com a era do comércio de escravas. Como declara a brochura dos Castelos de Elmina e da Costa do Cabo, "Entre elas, destacam-se as encenações dos horrores do tráfico de escravas, bem como um retrato solene e tocante da jornada final das africanas enquanto caminhavam pelas masmorras infernais para aguardar os navios que as transportaram para as Américas".

No entanto, o que isso significa para o nosso relacionamento com o passado quando a atrocidade se torna uma mercadoria para o consumo transnacional, e essa história de derrota passa a ser narrada como uma história de progresso e triunfo? Se as reecenações do cativeiro e da escravização eliminam a distinção entre sensacionalismo e testemunho, arriscam a sobriedade pelo espetáculo e ocluem a violência que pretendem representar; elas também criam uma memória do que não testemunhamos. A reconstituição do evento do cativeiro forja uma memória duradoura, visceral e pessoal do inimaginável. Esses encontros fabricados e tardios com a escravidão permitem uma revisitação do passado, que é apenas fugazmente visível na contemporaneidade impassível de África, recuperando origens no contexto de transações e trocas comerciais e experimentando a maravilha e o acolhimento possibilitados pelas narrativas de retorno. No contexto desse encontro com a morte, muita coisa se torna visível: a contínua crise da vida preta na era pós-direitos civis, a forclusão social do luto e o enlutamento como resposta aos limites e falhas da transformação política. Essencialmente, esses encontros tardios trazem à luz as promessas quebradas da liberdade.

\section{Encontro Um}

Uma placa localizada na entrada da área cercada ao redor do Castelo de Elmina adverte que ninguém é permitido dentro deste local, exceto turistas. Um grupo de meninos adolescentes 
está reunido além da entrada, desafiando obviamente essa ordem. Quando subo o caminho lamacento até a entrada do castelo, eles me cumprimentam: “Irmã!”, "Uma África!”, “A escravidão nos separou". Cada garoto me pede para ser sua amiga de correspondência, enquanto me entrega uma carta rabiscada nas páginas amassadas de um caderno escolar. As cartas são como pedidos de noivado prometendo que somos uma família. Cada um deles abre com a saudação "Querida irmã” ou "Amada irmã”. Apesar de saber que o amor prometido é alimentado pela fome, infligido pela inveja e pela desconfiança e precipitado pelas relações desiguais entre nós, sou atraída pela sedução da devoção filial estendida por esses amoristas emergentes. Por um momento, esses meninos e eu fazemos parte da mesma ninhada, amigos e parentes; de uma mesma casa, e não divididos em cafetões e benfeitora.

A “Amada Irmã” habilmente contorna e negocia acusações de amor e traição. As cartas dos meninos são itens de estoque nos circuitos locais do turismo de raízes. O modo de produção artesanal e a narrativa rigidamente construída da escravidão, separação e deslocamento relatada nessas epístolas não falham em seu apelo.

A carta de Kwesi começa,

Por favor me escreva. Somos uma África que simples [sic] significa que somos as mesmas pessoas e sei que foi por causa do tráfico de escravas que você saiu daqui e foi para os EUA e quero que saiba que você é minha irmã e eu sou seu irmão de acordo com a história de nossas antepassadas e a África é nossa pátria, portanto, seja bem-vinda em casa (Akwaaba), por favor, vamo[s] manter contato por cartas para que possamos aprender um com o outro e nos conhecer bem como irmão e irmã. Compartilhe minhas saudações com meus outros irmãos e irmãs na América. Obrigado. Paz e amor para você irmã mais velha.

A carta de Isaac é curta. Em três linhas, ele afirma o básico: sua nota na escola, a necessidade de lápis e papel e meu status de órfã. Ele termina com uma advertência para que eu aprenda minha história ou corro o risco de não saber quem eu realmente sou: "Por causa do tráfico de escravas, você perde sua mãe; se você conhece sua história, você sabe de onde você vem”.

Francis Mensah escreve: "Não se esqueça de me escrever porque somos uma África, o que simples [sic] significa que somos o mesmo povo, mas somente por causa do tráfico de escravas, é por isso que você perde sua terra-mãe para outro país e esta é a hora em que devemos aprender umas com as outras e entender a nós mesmas como irmãos e irmãs, e que 
aquelas que morrem no caminho para a América retornem à terra-mãe e eu sempre me lembro de todos os meus irmãos e irmãs da África em minhas orações e que Deus as abençoe para viverem em longevidade e prosperidade e espero que você nunca se esqueça de escrever para o irmão da África e você sabe que é muito doloroso que eles negociaram nossas ancestrais como escravas e eu fico muito triste sempre que leio a história do tráfico de escravas".

A pressa das declarativas nessas sentenças galopantes, a falta de pausa ou cesura, sem tempo para recuperar o fôlego, expressam inadvertidamente a presença duradoura da escravidão. Perco minha mãe de novo e de novo e de novo, não no passado, mas hoje. Kwesi, Isaac, Francis e eu existimos no doloroso presente do tráfico de escravas. Essas cartas forjadas e formuladas atacam anseios que eu sou relutante em admitir. Pois prefiro não reconhecer que a linguagem do parentesco ainda tem algum apelo. "Querida irmã” atravessa a armadura do meu ceticismo, que, como uma crosta que cobre uma ferida, é menos o sinal de recuperação do que uma barreira contra o ainda pulsante estado de lesão.

Sem essa defesa, sou exposta e vulnerável, uma mulher ingênua em uma missão impossível: a busca por parentes mortas e esquecidas. E esses garotos pubescentes fazendo negócios em troca de canetas e alguns trocados são a ponte através da qual eu viajaria para o meu passado. Na terrível luta por uns pouco trocados, imagino a Etiópia estendendo a mão. Na prosa clichê e roubada de suas cartas, vejo minha redenção. Visto orgulhosamente o título de irmã mais velha, apesar de saber que os termos de carinho e afiliação são parte integrante da língua franca do comércio. Entro em guerra comigo mesma em uma batalha entre o desejo e o discernimento. A escravidão negou à cativa todas as reivindicações de parentesco e comunidade; essa perda da afiliação natal e a dor duradoura das antepassadas que permanecem anônimas ainda assombram as descendentes das escravizadas. "Querida irmã" estende a promessa de afiliações restauradas, mas é um placebo, uma pretensa cura para uma lesão irreparável. Em Elmina, irmã e irmão são uma espécie de moeda e, como tal, esses afetos circulam promiscuamente. Esses adolescentes desalinhados, bolsos cheios de sonhos de retorno e promessas de pertencimento, brincam com meus anseios; seus presentes de sodalidade fugazes e evanescentes me cortam rapidamente.

Encontros tardios. A jornada ao "lar" é sempre uma jornada de volta, isto é, de volta no tempo, uma vez que a identificação com África como um local originário ocorre por meio da experiência da escravidão. E, acima de tudo, é um retorno tardio. Chega-se tarde demais para recuperar uma identidade autêntica ou estabelecer um parentesco com um lugar ou povo. Por 
fim, esses encontros ou jornadas ocorrem tarde demais, muito tempo após o evento, para serem considerados um retorno. Em resumo, não é possível voltar para casa. Tampouco é um encontro com África em sua contemporaneidade; o presente é eclipsado por um momento anterior - o evento do cativeiro e a experiência de escravidão nas Américas. É o encontro daquelas que vieram após "esse evento" - a Travessia e, depois, a escravidão. Mais importante, esse atraso pode ser considerado uma característica essencial da diáspora, pois, como observa James Clifford, as diásporas geralmente pressupõem "um tabu constitutivo sobre o retorno", motivo pelo qual o lar é aquilo que já está sempre perdido. É essa perda que sublinha a impossibilidade de retorno e o inevitável atraso desses encontros. É interessante notar que as moradoras da Costa do Cabo e de Elmina também invocam a noção de tardio para descrever o encontro afroamericano com África. Frequentemente, as afro-americanas são identificadas em Fanti ${ }^{13}$ como "asika fo amba ntem" - as ricas que chegaram tarde demais, se estivessem aqui antes, não sabemos o que teriam feito. ${ }^{14}$

Basicamente, esses encontros tardios iluminam as temporalidades díspares da ausência de liberdade. ${ }^{15} \mathrm{O}$ encontro com uma anterioridade aparentemente remota do passado - a escravidão e o tráfico transatlântico de escravos - fornece um instrumento para articular as promessas desfiguradas do presente, quais sejam, igualdade, liberdade da discriminação, abolição dos emblemas da escravidão, e assim por diante. Em resumo, o que fica nítido é que o passado não é nem remoto nem distante e que África é vista, se muito, através de um olhar para trás ou em retrospectiva. Por essas razões, é crucial considerar a questão do luto, pois ela incide sobre a imaginação política da diáspora, na interrogação da identidade nacional dos Estados Unidos, e na elaboração de contra-narrativas históricas. Em outras palavras, com que finalidade o fantasma da escravidão é invocado?

13 Fante, fanti ou fânti é uma das línguas faladas em Gana pelos fantes, pertencente como dialeto à língua acã das línguas nigero-congolesas.[N.T.]

14 Essa frase também sugere que as recém-ricas exibem ostensivamente sua riqueza.

15 Homi Bhabha descreve as dimensões do presente disjuntivo como a encenação de um passado "cujo valor iterativo como um signo reinscreve as 'lições do passado' na própria textualidade do presente", a reiteração e reencenação desses encontros e o papel do trauma na geração da identidade diaspórica. Ele observa que para as minorias, migrantes e outras identidades políticas emergentes, a "passagem pela modernidade produz essa forma de repetição - o passado como projetivo. O lapso de tempo da modernidade pós-colonial avança, apagando o passado complacente amarrado ao mito do progresso, ordenado em binarismos de sua lógica cultural: passado / presente, dentro / fora. Esse avanço não é teleológico nem é um deslizamento sem fim. É função do tardio [lag] desacelerar o tempo linear e progressivo da modernidade para revelar seu 'gesto', seu tempo [tempi], 'as pausas e tensões de toda a performance'... Essa desaceleração, ou atraso, impele o 'passado', projeta-o, dá a seus símbolos 'mortos' a vida circulatória do 'sinal' do presente, da passagem, a aceleração do cotidiano.” Ver Homi Bhabha: "Race, 'Time, and the Revision of Modernity" em The Location of Culture (New York: Routledge).

Periódicus, Salvador, n. 14, v.1, nov.2020-abr.2021 - Revista de estudos indisciplinares em gêneros e sexualidades Publicação periódica vinculada ao Núcleo de Pesquisa NuCuS, da Universidade Federal da Bahia - UFBA ISSN: 2358-0844 - Endereço: http://www.portalseer.ufba.br/index.php/revistaperiodicus 
O que está em jogo aqui é mais do que expor o artifício das barricadas históricas ou a fragilidade de marcadores temporais como passado e presente. Ao se apossar do passado, iluminam-se as promessas quebradas e os contratos violados do presente. A disjunção entre o que David Scott descreveu como "aquele evento" e "essa memória", além de abarcar uma dimensão essencial do tardio, levanta uma série de perguntas sobre o uso e a relevância do passado, a valência política e ética da memória coletiva, e a relação entre responsabilidade histórica e a crise contemporânea compreendida em termos de um apego masoquista ao passado, à intransigência do racismo ou ao intratável e duradouro legado da escravidão. ${ }^{16}$ Em outras palavras, a África como uma terra atávica, bem como o caráter e as consequências de uma identificação com África são mediados pela experiência da escravidão e, por vezes ainda mais importante, também como um olhar retrospectivo sobre a história dos EUA. Ou seja, a identificação com África já está sempre depois da quebra.

Ademais, existe a questão de saber se África serve apenas como um espelho que reflete a imagem dos Estados Unidos, permitindo assim que a 'repatriada' explore questões do lar e da identidade com uma medida de distância contemplativa. Certamente, isso não é surpreendente quando levamos em conta a maneira pela qual escravidão e África funcionam como "os pontos de referência generativos e constitutivos" nas narrativas continuistas da história Afro-Americana e da sobrevivência cultural. ${ }^{17}$ Por esse motivo, é importante desagregar África e escravidão, a fim de apreender as maneiras pelas quais elas se reúnem.

A viagem ao Castelo de Elmina, Ouidah ou Ilha de Gorée é, antes de tudo, uma maneira de celebrar a escravidão em seu suposto local de origem, embora se pudesse facilmente viajar para Portugal ou visitar o Vaticano. O paradoxo aqui é que o título de lar e o parentesco surgem somente como consequência do deslocamento e da morte da Travessia, e da morte social da escravidão; em resumo, é uma resposta à fratura da separação. O parentesco é precioso em virtude de sua dissolução, e o "parentesco ferido" define a diáspora. ${ }^{18}$ A visão imaculada e idealizada de lar e de parentesco é ainda mais estimada como conseqüência de sua impureza.

16 David Scott, 'That Event, This Memory: Notes on the Anthropology of African Diasporas in the New World Diaspora I (1991) p.84- 261.

17 Ibid, 262.

18 Esse termo é emprestado de Nathaniel Mackey's Bedouin Hornbook (Charlottesville: University Press of Virginia,). Fred Moten em Event Music (Minneapolis: University of Minnesota Press, no prelo) trouxe à minha atenção. 
Dessa maneira, não é diferente da virgindade, que como Faulkner observou "deve depender de sua perda, de sua ausência, para chegar a ter existência”.

A dissolução do eu [self] ou o afastamento da terra ancestral precede necessariamente "a conquista de uma identidade completa, restaurada e autêntica" oferecida pelo retorno. Ou seja, a escravidão media fundamentalmente essa identificação diaspórica com África e acentua o que Kobena Mercer descreveu como o componente essencial da identidade diaspórica - "a ruptura entre eu e minhas origens". Contudo, se essa ruptura engendra identidade diaspórica, então a busca por raízes só pode exacerbar a sensação de ser estranho, intensificar a consciência exílica e confirmar a impossibilidade de reversão. ${ }^{19} \mathrm{O}$ anseio por uma identidade autêntica e o tão esperado encontro com África agrava a crise da falta de lar.

As complexas e ambivalentes formas de identificação e desidentificação entre África e Estados Unidos, facilitadas nessas excursões, sugerem uma ansiedade em relação ao lar, isso é, um medo de que ser estrangeira em uma terra estranha possa ser uma condição incorrigível em solo nativo e terra ancestral. No final, essas peregrinações podem ser menos sobre a busca ou reivindicação do lar, do que expressões das contrariedades do lar. Deixe-me esclarecer que minha intenção aqui não é reinscrever um relato racialista da diáspora, posicionar África como terra originária, sugerir que a identidade diaspórica é melhor explicada pelo eixo singular da reivindicação, ou cair no que Gerald Early descrever como a "fascinação confusa" das pretas americanas diante das coisas africanas, mas antes interrogar a estrutura dominante desse encontro com o passado e elucidar seu caráter controverso. ${ }^{20}$

Como sugere David Scott, os tipos de questões que precisam ser feitas sobre o lugar de África no discurso político e cultural da diáspora não precisam fazer nenhuma reivindicação a respeito "do status ontológico supremo de África e da escravidão no presente das culturas do Novo Mundo". Assim, a tarefa importante aqui não é afirmar a genuinidade ou falsidade dessas afirmações, estabelecendo a presença verificável de África na diáspora, ou refutar essa conexão, insistindo que não existe uma relação essencial, porque a África é um significante vazio ou a raça é um falso terreno para a identidade. Ao invés disso, Scott encoraja-nos a considerar "os modos pelos quais África e escravidão são empregadas [...] na construção narrativa das relações

19 Eduoard Glissant, Caribbean Discourse, tradução para o inglês de Michael Dash (Charlottesville: University Press of Virginia, 1989). p.14-18

20 Gerald Early, "The American Mysticism of Remembrance," em The Culture of Bruising: Essays on Prizefighting, Literature, and Modern American Culture (Hopewell, NJ: Ecco Press, 1994). p.127 
entre passados, presentes e futuros [e] o trabalho retórico ou ideológico que elas são condicionados a performar".

A ponte entre a África e as Américas é articulada negativamente em termos de separação, das mortas não lembradas e do status de segunda classe das afro-americanas nos Estados Unidos. Ou, como observa Toni Morrison, "é transposta para nós pela responsabilidade assumida por pessoas pelas quais ninguém assumiu responsabilidade". O lugar que África ocupa na imaginação política e histórica é complicado, uma vez que a origem é figurada como perda, e o conto de tornar-se é uma morte anunciada. Mais importante, a fabulação de narrativas de continuidade está enredada em uma crítica do presente, uma vez que esses encontros reformulam a história do tráfico do ponto de vista da diáspora norte-americana e refletem criticamente sobre o significado da identidade nacional dos EUA. Ou seja, a construção ideológica do passado é guiada pelos atuais interesses políticos da diáspora; de fato, as inevitáveis desfigurações do presente articulam o significado de uma identidade diaspórica e nacional dos EUA. O passado chamado África nessas narrativas é, em muito, uma história do presente. O passado interrompe o presente não em virtude da afinidade cultural ou do status de África como "origem cultural autêntica da diáspora"', mas por causa do legado vigente desse cativeiro e deslocamento. ${ }^{21}$

O que se torna visível, apesar da proclamada unanimidade das ancestrais e suas descendentes no pronunciamento comum "Você está de volta", é a ambivalência da identificação com a África forjada nesses encontros. Afinal, a origem identificada é o local da ruptura e, ironicamente, os fortes e castelos construídos pelos europeus tornam o lar mais próximo. A perda predomina neste local de origem imaginado, uma vez que a gênese da diáspora está localizada nessa deportação comercial. Esse lar estranhado sugere que esse estado de exílio e estranhamento pode ser inescapável. ${ }^{22}$ Também não é fácil reivindicar uma identidade africana, pois é provável que se seja chamada de obroni, que significa "estrangeira" ou "branca", assim como "irmã" e essas saudações realmente alcançam uma estranha igualdade como designações de relações de troca, marcadores de estranheza e incentivos para comprar. Embora lembrar da "angústia das antepassadas" seja um aspecto central da peregrinação a esses monumentos do comércio transatlântico, a recursão também é informada pelos imperativos e anseios do presente. Ou seja, a desapropriação é ela mesma uma herança que nos amarra "àquele evento". Sujeição racial, encarceramento, empobrecimento e cidadania de segunda classe: esse é o legado da 
escravidão que ainda nos assombra. ${ }^{23}$ A duração da ferida e o caráter aparentemente intratável de nossa derrota são responsáveis pela presença viva da escravidão e também pela reparação oferecida pelo turismo.

Uma travessia reversa? Na Porta do Não Retorno [Door of No Return] - a passagem do calabouço para o navio negreiro - o guia declara, "Não é realmente a porta do não retorno, porque agora você voltou!". Essas palavras projetam a turista como a cativa triunfante e descendente que retorna. Essa proclamação, regularmente emitida na saída final, é o momento último de convergência entre passado e presente, e nisto revela o dilema do luto como reconhecimento da perda e substituição do objeto perdido por meio da identificação.

O retorno é uma fantasia de origens; é da classe de fantasias que Jean Laplanche e J. B. Pontalis descrevem como primárias. Semelhante aos mitos coletivos, essas fantasias "fornecem representação e solução para o que quer que se constitua como enigma importante para a criança" e "dramatiza o momento primário ou o ponto de partida original de uma história. $\mathrm{Na}$ 'cena primária', é a origem do sujeito que é representada." 24

Nitidamente, a cena primária que explica a origem do sujeito é o evento de cativeiro e escravização; assim, os locais aos quais se retorna são os calabouços, barracões [barracoons] e casas de escravas da costa oeste de África. A jornada pelos calabouços é um tipo de viagem no tempo que transporta a turista para o passado. Não apenas essas fantasias têm origens complicadas e diversas, mas sua representação não é menos controversa; porque a identificação das origens, o drama do retorno e o estágio de recuperação são levados adiante com uma consciência tanto da impossibilidade como da necessidade de corrigir o irreparável.

No portal que simbolizava o caráter definitivo da partida e a impossibilidade de reversão, as tensões que residem no luto pelas mortas são experimentadas com mais intensidade. O luto é duplamente uma expressão da perda que nos amarra às mortas e corta essa conexão ou uma superação da perda ao assumir o lugar das mortas. O excesso de empatia nos leva a confundir nosso retorno com o das cativas. Na medida em que as enlutadas tentam entender esse espaço da

23 Essa não é uma sugestão que o racismo é imutável, mas uma ênfase no caráter intransigente do racismo e do fato de que a condição de alguém ainda é largamente definida pela sua filiação ao grupo de sujeitos.

24 Jean Laplanche and J. B. Pontalis, "Primal Phantasies," in The Language of Psycho-analysis, tradução para o inglês de Donald Nicholson-Smith (New York: Norton, 1973 ), p.332. 
morte, colocando-se na posição de cativas, a perda é atenuada e não discutida, e a presença fantasmagórica das que partiram e das mortas eclipsada pelo nosso cativeiro simulado.

"Você está de volta!" Somos encorajadas a nos vermos como embarcações para o retorno da cativa; estamos no lugar da ancestral. Testemunhamos imaginativamente os crimes do passado e clamamos pelas que foram vítimas - as escravizadas, as saqueadas e as abatidas. E a assimilação obliterante da empatia nos permite também chorar por nós mesmas. Ao nos lembrarmos daquelas ancestrais mantidas nos cativeiros, não podemos deixar de pensar em nossas próprias vidas desonradas e desvalorizadas, nas aspirações não realizadas e nas promessas quebradas de abolição, reconstrução, e o movimento por direitos civis. A intransigência de nosso status aparentemente eterno de segunda classe nos leva a recorrer a histórias de origem, inabaláveis explanações narrativas e locais de injúria - a terra onde nosso sangue foi derramado como se algum ingrediente essencial de nós mesmas pudesse ser recuperado nos castelos e fortalezas que pontilham a costa oeste de África, como se a localização da ferida fosse a própria cura, ou como se o peso das gerações mortas pudesse por si só garantir o nosso progresso.

Ironicamente, a afirmação "Você está de volta!" desabilita a própria violência que esses memoriais assiduamente trabalham para apresentar através da reivindicação de que a excursão turística é o retorno da ancestral. Diante disto, o que a jornada de volta pressagia para o presente? O que é surpreendente é que, a despeito da ênfase depositada na memória e no retorno, essas cerimônias são na verdade incapazes de articular de maneira decisiva, algo além da reclamação de uma identidade verdadeira que a lembrança produz. Enquanto a jornada de volta é o veículo da remediação, da recuperação, e da auto-avaliação, a questão que se coloca é o que seria exatamente o trabalho compensatório atualizado pela lembrança. A espetacular abjeção da escravidão não é reproduzida em representações fáceis do horror do tráfico de escravos? Que fins são oferecidos por essas representações, além de lembrar das falências da memória através de encenações dramáticas do cativeiro e da incorporação das mortas? $\mathrm{O}$ aspecto mais perturbador dessas encenações é a sugestão que a ruptura da travessia não é nem irreparável nem irrevogável, mas transportada pela turista que atua como uma embarcação para a ancestral. Em resumo, a cativa encontra sua redenção na turista.

A celebração do retorno na verdade ameaça minar o trabalho do luto "simulando a condição de intacto", no lugar de tratar das ruínas e destroços da escravidão, e declarando que as 
deportadas de fato retornaram através de suas descendentes. ${ }^{25}$ No calabouço, a história da queda é narrada como a história do progresso. A facilidade com que "o maior crime da humanidade" é invocado e instantaneamente eclipsado pela celebração do retorno daquelas descendentes da travessia sugere que, em última instância a linguagem do retorno opera para negar a própria violência a qual supostamente dá voz e insinua que os distúrbios da comércio escravista possam ser reparados. ${ }^{26}$

\section{Encontro dois}

Na Casa dos Escravos, na Ilha de Gorée, juntei-me a um grupo de turistas afroamericanas de Miami composto principalmente por professoras e enfermeiras aposentadas. O curador da casa de escravas, Boubacar N’Diaye, sintonizado com os anseios das turistas afroamericanas, conta uma história da escravidão projetada para remediar seus ferimentos e confirmar a excepcionalidade afro-americana. Narrando a história do comércio escravista, N'Diaye descreve aquelas capturadas e levadas para as Américas como as pessoas mais bonitas em África e, como prova disso, ele aponta a superioridade física das atletas afro-americanas. Para nós, ele elabora sobre se juntar ao grupo, como se tivesse decidido se juntar a nós por causa da auspiciosidade de nosso retorno, e promete que será um tour especial porque voltamos para casa. Essa espontaneidade encenada aparentemente não é necessária para turistas europeias, e apesar de suas afirmações em contrário, todos os tours são iguais, exceto pelo notável silêncio em torno do racismo e pelo fracasso dele em partilhar sua crítica à participação da igreja no tráfico de escravizadas ou comparar o comércio escravista com o holocausto quando guia europeus pela casa de escravas. O tom especial voltado para as afro-americanas confere a cada observação uma gravidade indevida, consagra cada objeto, requer ajudantes especiais para escoltar aqueles que gritam do calabouço das crianças até a Porta do Não Retorno, e, finalmente, lança N'Diaye não apenas como guardião da memória, mas como escravo original. Um enorme retrato dele vestindo uma tanga, algemado e estendido na Porta do não Retorno, está pendurado na loja do museu.

25 Eric Santner, "History beyond the Pleasure Principle: Some Thoughts on the Representation of Trauma," in Probing the Limits of Representation: Nazism and the Final Solution, ed. Saul Friedlander (Cambridge: Harvard University Press, 1992), p.144.

26 A Declaração de Accra afirma que o comércio de escravos é "a maior tragédia da história do homem por causa de seu escopo e duração." 
O tour pela casa das escravizadas é extremamente apressado, a fim de colocar grandes grupos para dentro e para fora de vinte à trinta minutos. Além da estranha coleção de detalhes e anedotas, escassas informações históricas são fornecidas no passeio. Induzir as visitantes pretas a debulharem-se em lágrimas parece ser o seu objetivo principal. O tour se inicia no calabouço das crianças. Ao entrar no calabouço das crianças, algumas das mulheres começam a chorar. Estou surpresa visto que tenho sido incapaz de derramar uma única lágrima; aliás, esse passeio fajuto e sensacionalista incita a minha raiva, que parece a única emoção que posso expressar com alguma facilidade. No entanto, observando essas mulheres, percebo que elas vieram aqui para servir como testemunhas, prestar respeito aquelas que foram mantidas em cativeiro, e velar devidamente aquelas descritas por Morrison como "as enterradas sem cerimônia", independentemente dos engodos e clichês do turismo de raízes. Elas são auxiliadas por e indiferentes à indução de N'Diaye. Minha própria auto-encenação [self-fashioning] reativa como uma "anti-turista" parece cínica, adolescente, e, finalmente, uma falha em lidar com os bagunçados emaranhados de memória, da mercantilização, do terror e do turismo.

Não estou tentando sugerir que essas mulheres que choram são modelos exemplares de enlutamento, especialmente dada a facilidade com a qual o grupo se desloca das lágrimas para um retrato sorridente em frente à Porta do Não Retorno, para uma tarde de compras; de fato, é bastante difícil, se não impossível, separar o luto que excede o turismo da catarse contida promovida por ele. Ainda assim, é importante considerar a possibilidade do luto como uma contranarrativa às exclusões da história nacional dos EUA e à apreensão pessoal e apropriação dos recursos narrativos disponibilizados pelo turismo. Em resumo, tudo o que estou sugerindo é que as lágrimas derramadas por essas mulheres podem exceder as limitações do turismo, ainda que apenas momentaneamente, e esse pesar pode ser uma forma de se engajar criticamente com o passado, ou, pelo menos, uma forma que coloca a emancipação em crise. Como W. E. B. Du Bois observou um século atrás, o desespero foi mais aguçado do que atenuado pela emancipação. Na face das libertadas, não tendo encontrado liberdade na terra prometida, poderia ser vista a 'sombra de uma profunda decepção'. Lágrimas e decepção criam uma abertura para uma contra-história [counterhistory], uma história [story] escrita em oposição à narrativa do progresso. Lágrimas revelam que o tempo da escravidão persiste nesta interminável espera — isto é, esperando a liberdade e ansiando por uma maneira de desfazer o passado. As temporalidades abrasivas e incomensuráveis do "não mais" e do "ainda não" podem ser vislumbradas nessas lágrimas.

O luto torna visível o objeto perdido, definido de várias maneiras como a terra natal, a identidade autêntica e / ou a possibilidade de pertencimento. Também se dirige ao desprezo do 
pesar como mimimi e ao recalque da escravidão na memória nacional. Certamente, o uso da palavra perda tensiona-se com a complexidade do evento e das suas consequências e corre o risco de impor uma narrativa limpinha de continuidade entre aquele evento e essa condição. Ainda assim, o trabalho de luto, se não é dedicado a estabelecer essas conexões, pelo menos, é bem sucedido em criá-las. Na Porta do Não Retorno, a litania de cativas levadas para os Estados Unidos, Haiti, Brasil, Suriname, Jamaica e assim por diante, mapeia as linhas de afiliação entre várias partes das Américas. Ao recontar a saga do cativeiro e da escravização, um eixo particular de identificação emerge - a crônica da escravidão rende-se ao terror cotidiano do racismo, ao movimento dos direitos civis, e louva a um panteão de afro-americanas, incluindo W. E. B. Du Bois, os irmãos Nicholas, Martin Luther King, Muhammad Ali e Angela Davis.

Nesse sentido, a história do tráfico de escravas e a narrativa da diáspora relatada nesses locais privilegiam a localização social e a experiência histórica das pretas nos Estados Unidos. Cativeiro, conduta, escravidão, Jim Crow e uma tão esperada integração e igualdade - essa narrativa é reforçada pelas estratégias de desenvolvimento dos estados africanos, pelos incentivos do Ministério do Turismo, as diretrizes da Agência dos Estados Unidos para o Desenvolvimento Internacional [United States Agency for International Development - USAID] e a acuidade de comerciantes mesquinhos. Ironicamente, como resultado desses esforços combinados, a escravidão se torna novamente uma história distintamente americana, com uma breve menção dos 'traidores africanos', 'mas com pouca referência ao impacto da escravidão em África ou nas regiões agora conhecidas como Gana e Senegal.

Não obstante os limites do turismo da rota de escravas, nesses locais a crônica de desapropriação e dominação, que com frequência é contida, localizada e descartada nos Estados Unidos pela rubrica "história preta", recebe reconhecimento oficial, ao menos pela UNESCO e pelos estados africanos participantes do Projeto Rota dos Escravos, como uma das "maiores tragédias humanas". As oportunidades de testemunho e lembrança encorajadas aqui centralizam a presença marginalizada do comércio transatlântico de escravas. Na melhor das hipóteses, esses lugares de memória fornecem um espaço público para lamentar, um espaço em que o pesar preto não é feito de material de entretenimento nacional e interesse lascivo, uma vez que nem as milhões de vidas perdidas no comércio transatlântico nem o legado duradouro da escravidão ainda não foram reconhecidos no contexto nacional dos EUA, onde a voz ofendida é descartada 
como "reclamona e chorona". ${ }^{27} \mathrm{O}$ descarte ou refutação do legado duradouro da escravidão, sem surpresa, emprega a linguagem do progresso e, ao fazê-lo, estabelece o distanciamento e a irrelevância do passado. Como uma conseqüência dessa postura, as reivindicações de reparação baseadas nessa história e em seu legado duradouro são desqualificadas e menosprezadas como ridículas ou ininteligíveis, com alguns críticos conservadores indo tão longe a ponto de difamarem essas próprias reivindicações como atos racistas.

O luto, como uma expressão pública do pesar de alguém, insiste que o passado ainda não acabou; essa compulsão ao pesar também indica que o remédio liberal ainda precisa ser uma solução para a dominação e a desigualdade racistas. Agarrar-se ao passado é uma maneira de lamentar as circunstâncias atuais e combater a desqualificação regular das reivindicações de reparação como reclamação, inveja e uma barreira ao avanço social, portanto, dar voz ao pesar da diáspora é especialmente importante à luz da "extrema discrição da comunidade acadêmica" em relação ao tráfico de escravas e o desprezo loquaz ou apoio condescendente que só pode entender essas lamentações, ou qualquer esforço para enfrentar a quebra e ruptura induzida pelo tráfico de escravas, como ainda mais um exemplo de mimetismo Preto ou do "holocausto em blackface". ${ }^{28} \mathrm{Na}$ medida em que permite que as lesadas recontem a história que engendrou a degradação da escravidão e a constituição prejudicial da pretitude [blackness], o luto pode ser considerado uma prática de contramemória que trata daquilo que foi negado e reprimido.

No entanto, o trabalho do luto não deixa de ter seus perigos, carro chefe entre eles é o limite escorregadio entre responsabilidade e assimilação e testemunho e incorporação. Podemos nos enlutar por aquelas perdidas sem assumir e usurpar o lugar das mortas, e ainda assim reconhecer que as injúrias do racismo nos amarram a esse passado? O luto implica necessariamente a obliteração da outra através da identificação? Podemos velar as mortas sem nos tornarmos elas? As cerimônias do turismo das rotas de escravas e a fantasia do retorno sugerem o contrário - lembrar das mortas é assumir o seu lugar. No entanto, o luto não precisa implicar calçar os sapatos das antepassadas ou negar a diferença entre nós e elas com a tacada da identificação. Em outras palavras, podemos criar uma visão emancipatória sem a premissa de recuperação ou desvincular o luto da superação do passado? Embora o pesar da diáspora e os anseios por retorno ameacem substituir a experiência daquelas capturadas e escravizadas por

27 Hortense Spillers, “Moanin', Bitchin', and Melancholia', 1996.

28 Stanley Crouch descreveu Amada, de Toni Morrison, como um romance do holocausto em preto. Veja seu Notes of a Hanging Judge (Nova York: Oxford University Press, 1990). 
nosso próprio cativeiro simulado, negar a finalidade da deportação com nossa presença tardia e obscurecer a diferença entre esse evento e seu legado duradouro, mesmo assim, ainda é necessário enlutar-se, uma necessidade aumentada pela ubiquidade do ataque racista, a proibição desse espaço de luto nos Estados Unidos e a falta de vontade de declarar a escravidão um crime contra a humanidade.

História que dói. O calabouço não fornece redenção alguma. Acertar as contas com nossa responsabilidade para com as mortas não pode salvá-las. O vitorioso já venceu. Não é possível desfazer o passado. Então, com que finalidade conjuramos a fantasma? De que serve um itinerário do terror? Ela fornece um pouco mais do que evidências do que não podemos mudar, ou aplaca a incerteza e a dúvida que diz respeito a milhões de perdidas e desconhecidas? O debate ainda inflama-se sobre quantas foram transportadas para as Américas, mortas nos ataques e guerras que supriram o comércio, pereceram na longa jornada para a costa, cometeram suicídio, morreram de desidratação durante a travessia, ou foram espancadas ou forçadas a trabalhar até a morte — 22 milhões, 30 milhões, 60 milhões, ou mais? ? $^{29}$ Não é o suficiente saber que para cada cativa que sobreviveu à provação do cativeiro e da sazonalidade pelo menos uma não o fez?

Na melhor das hipóteses, o pano de fundo dessa derrota torna visível a violência difusa e as rotinas diárias de dominação, que continuam a caracterizar a vida preta, mas são obscurecidos pela sua cotidianidade. O caráter normativo do terror garante a sua invisibilidade; resiste à detecção por trás de categorias racionais como crime, pobreza e patologia. Em outras palavras, a necessidade de sublinhar a centralidade do evento, definido aqui em termos de cativeiro, deportação e morte social, é um sintoma da dificuldade de representar o 'terror como de costume'. A oscilação entre então e agora destila os últimos quatrocentos anos em um momento definitivo. E, ao mesmo tempo, a narrativa ainda em desenvolvimento do cativeiro e da desapropriação excede os parâmetros discretos do evento. Ao listar a longa lista de violações, estamos mais próximas da liberdade ou essas litanias apenas confirmam o que é temido — a história é uma lesão que ainda não cessou de acontecer?

29 Estimativas sobre o número de africanas transportadas para as Américas e perdidas em ataques, guerra, viagens terrestres e marítimas, e assim por diante, variam entre 15 e 210 milhões. O sumário relatório da conferência da UNESCO sobre o comércio de escravas africanas realizada em Port-au-Prince, Haiti, em 1978 estados, “Apesar dos esforços sérios nos últimos anos para alcançar uma ampla conclusão, diferenças na avaliação da extensão global do comércio de escravas permanecem agudo... As perdas da África durante os quatro séculos do comércio de escravas no Atlântico devem ser colocadas em cerca de 210 milhões de seres humanos. De acordo com outros, o total geral de escravas transportadas entre os séculos X e XIX deve ser colocado entre 15 e 30 milhões de pessoas "(O tráfico de escravos africanos do século XV ao século XIX [Paris: UNESCO, 1979), p.212 - 13. 
Dada a natureza irreparável deste evento, que Jamaica Kincaid descreve como um erro que pode ser abrandado apenas pelo impossível, isto é, por desfazer o passado, é encenar o passado a melhor aproximação de translaboração disponível para nós? Ao sofrer o passado, somos mais capazes de agarrar uma liberdade elusiva e torná-la substancial? A dor é a garantia da compensação? Além de contemplar injúrias ou atribuir culpas, como pode esse encontro com o passado incendiar esforços emancipatórios? É suficiente que esses atos de comemoração resgatem as não nomeadas e as não-contabilizadas para longe da obscuridade e do esquecimento, combatam as negações constitutivas da comunidade nacional dos EUA e desvendem a cumplicidade discreta do financiamento acadêmico dos estudos do comércio?

Colocando francamente, existe uma relação necessária entre lembrança e reparação? A criação de uma memória coletiva de crimes passados pode garantir o fim da injustiça? ${ }^{30}$ Pode a monumentalização do passado ser suficiente para evitar atrocidades? Ou consegue apenas enquadrar esses crimes contra a humanidade a partir da posição estratégica do progresso e da razão contemporâneos, transformando a história em um grande museu no qual nos deleitamos com excesso de antiquários? Podemos obter uma mínima pista 'desse evento' passando meia hora nas masmorras? Eu não estou tentando desmerecer esses engajamentos com o passado, mas apenas abalar nossa confiança na comemoração e nos conceitos que a acompanham sobre a paz mundial e a história universal, implicados na designação desses monumentos como locais do Patrimônio Mundial da Humanidade e, também, considerar se o cativeiro imaginado e simulado não funciona de fato para fins contrários — se não minimiza o próprio terror que se propõe a representar através dessas reencenações mundanas.

O ponto aqui não é o de condenar o turismo, mas o de examinar rigorosamente as políticas da memória e questionar se a "translaboração" ["working through"] é mesmo um modelo apropriado para o nosso relacionamento com a história. Em "Representing the Holocaust", Dominick LaCapra opta por translaborar como um caminho do meio entre a totalização redentora e a impossibilidade de representação e sugere que é possível um certo grau de recuperação no contexto de uma translaboração responsável do passado. Ele afirma que, ao aceitar o trauma, existe a possibilidade de recuperar aspectos desejáveis do passado que possam ser usados na reconstrução de uma nova vida. ${ }^{31}$ Embora os argumentos de LaCapra sejam persuasivos, pergunto-me até que ponto o olhar para trás pode nos fornecer uma visão para construir uma nova vida? Até que ponto

30 Steven Knapp, “Collective Memory and the Actual Past,' Representations, no. 26 (Spring 1989): 137. 31 Dominick LaCapra, Representing the Holocaust (Ithaca: Cornell University Press, 1994), p. 199. 
precisamos contar com o passado para transformar o presente ou, como Marx advertiu, podemos apenas aspirar nossa poesia do futuro e não do passado ? $^{32}$ Aqui não estou promovendo a impossibilidade da representação ou declarando o fim da história, mas imaginando em voz alta se a imagem das ancestrais escravizadas pode transformar o presente. Faço essa pergunta para descobrir novamente a relevância política e ética do passado.

Se o objetivo é algo mais do que assimilar o terror do passado em nosso armazém de memória, a pergunta premente é: Por que precisamos nos lembrar? A ênfase em lembrar e translaborar o passado expõe nossos desejos insaciáveis por curativos, cura, e qualquer outra coisa que ofereça uma restauração imaculada pré-lapsariana? Ou a lembrança é uma estrada para desfazer a história? A lembrança pode potencialmente permitir uma fuga da regularidade do terror e da rotina de violência constitutiva da vida preta nos Estados Unidos? Ou será que a lembrança se tornou a única forma concebível ou viável de agência política?

Normalmente, a moção para lembrar insiste que a memória pode impedir atrocidades, redimir as mortas e cultivar uma compreensão de nós mesmas tanto como indivíduas, tanto como sujeitas coletivas. Ainda assim, muito frequentemente, a moção para lembrar presume a facilidade de lidar com o terror, representando o crime da escravidão e habilmente colocando-se nos sapatos da outra. Não estou proibindo representações da travessia, particularmente porque é a ausência de uma história pública da escravidão e não a saturação da representação que gera essas performances compulsivas, mas, em vez disso, apontando para o perigo de invocações fáceis do cativeiro, frases de efeito sobre as milhões perdidas e simulações do passado que substituam o engajamento crítico.

Esses encontros com a escravidão são condicionados pela repressão e apagamento da história violenta de deportação e morte social na imaginação nacional, e as plantações pastorais e épicos de etnicidade que os substituem. A esse respeito, a jornada de volta é tão motivada pelo desejo de retornar ao local de origem e à cena da queda, quanto pela paisagem invisível da escravidão, os portos de entrada não marcados nos Estados Unidos e o imperativo nacional de esquecer a escravidão, torná-la como um romance ou relegá-la a algum tipo de pré-história que tem pouco a ver com o presente. As plantações restauradas do Sul fedem à falsa grandeza dos bons velhos tempos, e as cabanas não parecem horríveis o suficiente. Com muita facilidade, pode-se concluir: Bem, as coisas não eram de todo mal. A rigidez das masmorras parece permitir 
uma certa dignidade; seu vazio cavernoso ressoa com o indizível. Esses espaços em branco sugerem a enormidade da perda, as milhões desaparecidas e o que Amiri Baraka descreve como: "O espaço excedido, o espaço vazio em que vivemos, o espaço que restou de nossa história, agora um mistério".

Na masmorra, nós nos dedicamos singularmente à tarefa do luto. No buraco das escravas, o ideal perdido: mãe, lar, parentesco e aceno comunitário. A atração desses ideais não é em nenhum outro lugar tão dolorosamente aguda e absolutamente elusiva do que no espaço imaginado como a cena da nossa concepção. O luto nos permite uma visão fugaz do "antes", uma imagem de nós mesmas como "aquelas que nós nunca fomos". Nós prevemos a queda, nossos olhos se enchem com a visão de nossa antiga grandeza, nossos corações doem por causa das pessoas perdidas e dos ideais perdidos, perda redobrada e ricocheteando.

Neste lado do Atlântico, vislumbres de uma integridade pré-lapsariana seduzem e traem, mais do que a rotina entorpecente do trabalho, o desconhecimento deformante da escrava, nigger, criada; neste local, não é preciso reforçar a pobreza da tragédia ao imaginar a escravidão, ou participar dos inúmeros jogos que substituíram um engajamento sustentado com o passado. Não é preciso se esforçar para ouvir a voz de nossa queixa ainda retumbante. 